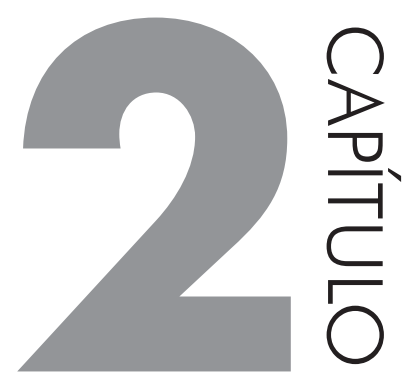

\title{
SÃO TOMÉ E PRÍNCIPE: aspectos históricos, econômico-sociais e linguísticos
}

\section{FABIANE DE MELLO VIANNA DA ROCHA TEIXEIRA RODRIGUES DO NASCIMENTO}

\section{INTRODUÇÃO}

Este capítulo ${ }^{1}$ expõe algumas informações históricas, socioeconômicas e linguísticas a respeito das ilhas de São Tomé e Príncipe, na tentativa de traçar um perfil sociolinguístico da região e explicar sua evolução desde o descobrimento até os dias atuais. Como ilustram as Figuras 1 e 2, São Tomé associa-se a Príncipe em um estado insular situado a aproximadamente $250 \mathrm{Km}$ da costa africana, no Golfo da Guiné.

1 Este capítulo foi integralmente reproduzido da tese de Nascimento (2018). 


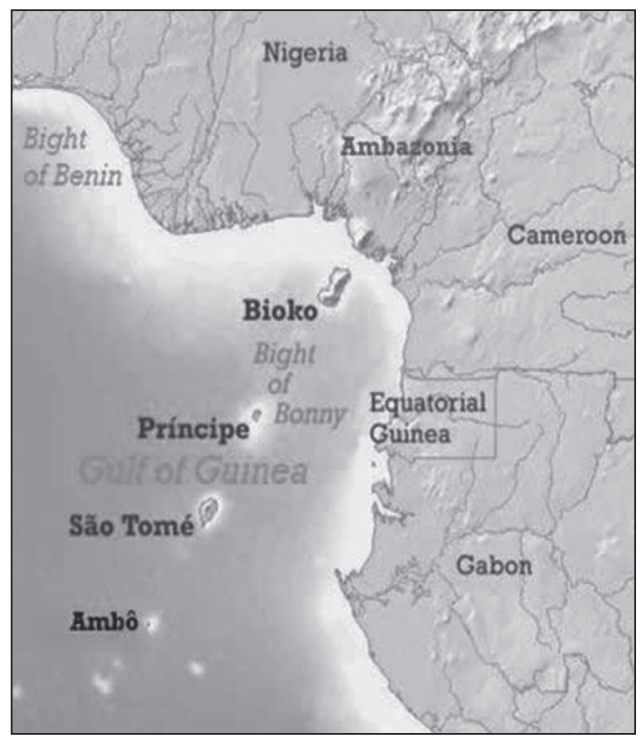

Figura 1 Localização de São Tomé, Príncipe e Ano Bom no Golfo da Guinéz

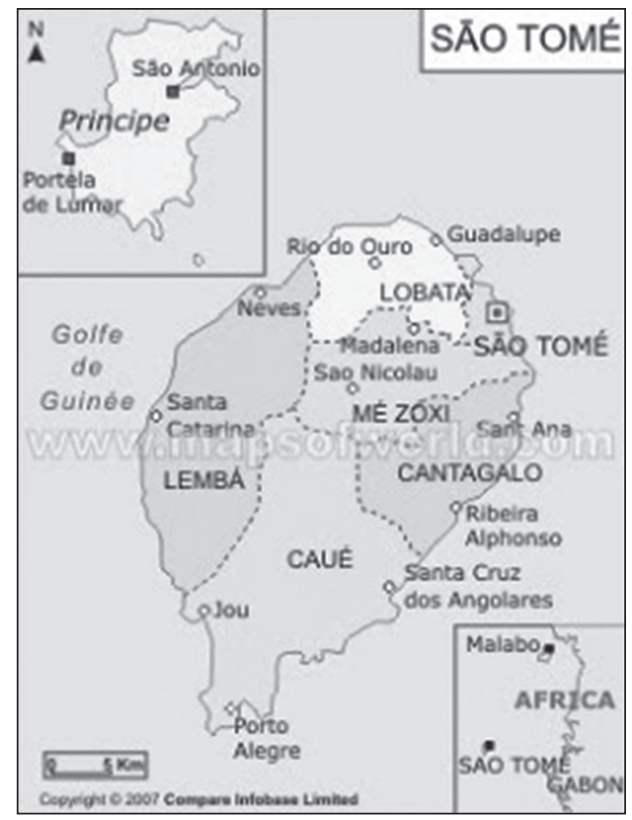

Figura 2 Distritos de São Tomé e de Príncipe ${ }^{3}$

2 Imagem extraída de https: //pt.wikipedia.org/wiki/Ano-Bom.

3 Imagem extraída de https: //www.google.pt/search?q=distritos+caue\&source=lnms\&tbm=isch \&sa=X\&ved=0ahUKEwiFx7Li9LzUAhXK1hoKHUf4DDsQ_AUIBigB\&biw=1371\&bih=571 
A escassez de documentos históricos dificulta a determinação das descobertas, mas estudos sobre o assunto remetem ao fim do século XV, relacionando suas trajetórias à de Ano Bom. ${ }^{4}$ Em cinco séculos de existência, vivenciou duas colonizações centrais, provenientes de dois ciclos econômicos dominantes e atuou como entreposto de escravos, sustentando o tráfico do Atlântico e se submetendo a intensos fluxos migratórios. $\mathrm{O}$ atual panorama linguístico da região decorre de povoamentos em massa, associados i) ao cultivo do açúcar, no século XVI; e ii) às culturas do café e do cacau, inauguradas no século XIX. A princípio, o convívio entre europeus e africanos, bem como a recorrência de entradas e saídas de cativos, culminaram com a formação e especiação do (proto)crioulo do Golfo da Guiné (doravante PCGG) (cf. seção 2.1). Tempos depois, a necessidade de um regime de contrato com trabalhadores de Cabo Verde, Angola, Moçambique, Benim e Gabão, contribuiu paulatinamente para a generalização do uso do Português (doravante PST) (cf. seção 2.2).

Segundo Ladhams (2007 apud BANDEIRA, 2017: 120), “o input linguístico apresentado pelo influxo cativo nos primeiros anos de colonização de São Tomé é complexo e possui contornos de difícil precisão". Desde o fim do século XV, a necessidade de diálogo entre colonizador e colonizados de diferentes origens promoveu um falar emergencial, que, uma vez complexificado e nativizado, resultou no PCGG. Representando frutos da especiação e expansão da língua-mãe, além do Português, do Caboverdiano e de resquícios de línguas bantas, coexistem em São Tomé i) o Forro (ou santomé), crioulo mais usado na ilha, e ii) o Angolar, utilizado no sudoeste e nos distritos de Cauê e Lembá, principalmente. Nas proximidades, encontram-se utentes iii) do Lung'ie, em Príncipe; e iv) do Fa d'ambô, cuja comunidade linguística se concentra em Ano Bom, a cerca de $150 \mathrm{~km}$ do Sul do país, no Oeste da África ${ }^{5}$ (cf. FERRAZ, 1979; HAGEMEIJER, 2009, 2001; GONÇALVES, 2016) (cf. seção 3.1).

De acordo com Hagemeijer (2009: 15), “a breve incursão na sintaxe não só mostra que os crioulos do Golfo da Guiné têm essencialmente a mesma estrutura mas também que as estratégias sintácticas se inclinam, em geral, para estratégias

$\& \mathrm{dpr}=1.4 \#$ tbm=isch\&q=distritos+sao+tome+e+principe+caue \&imgrc=96ytzIKYZKe9XM: \&spf=1497428761804

4 De acordo com Ferraz (1979: 9), o espaço era desabitado "até a chegada dos portugueses em datas que são geralmente situadas entre 1470 e 1472.” Contrariando essa visão, Campos (1971 apud Ferraz, 1979: 9) afirma que "São Tomé foi descoberta em 1478, Príncipe em 1479 e Ano Bom oito anos depois".

5 Atualmente, também se encontram falantes de Fa d'ambô na Ilha de Bioko e na diáspora (cf. HAGEMEIJER; ZAMORA; 2016: 193). 
(...) disponíveis no substrato Edo"6. Trata-se de sistemas que aliam um léxico predominantemente português (cerca de $90 \%$ ) a estruturas funcionais incorporadas da gramática das línguas africanas de que se formaram (GONÇALVES, 2016: 24). A gênese singular contrasta com a inteligibilidade limitada entre eles, fato justificável pela "separação no tempo e no espaço" e "pelas mudanças internas e externas (como contato linguístico posterior) que cada um sofreu depois de se ter separado do tronco comum" (HAGEMEIJER, no prelo a). Por isso, sobretudo nos níveis lexical e fonológico, o angolar, "apresentaria componentes mais marcadamente banto, ao passo que o Lung'ie, devido ao Príncipe ter recebido um maior número de escravos do Delta do Níger, apresentaria um componente mais marcadamente edo" (BANDEIRA, 2017: 119). Ao mesmo tempo, o Fa d'ambô compartilha $82 \%$ de seu léxico com o Forro. A influência africana nesses falares, "inferior a $10 \%$ do léxico global, é primeiramente derivada do Edo, a linguagem do antigo Reino de Benin na Nigéria, e do Quicongo, um grupo de línguas do oeste Banto falado no Congo e no Norte da Angola"7 (HAGEMEIJER; ZAMORA, 2016: 197).

As próximas seções aprofundam as informações históricas e linguísticas listadas, concentrando-se (seção 2) na fase de habitação e nos ciclos do açúcar (2.1), do café e do cacau (seção 2.2). No que tange ao multilinguismo (seção 3), expõem-se dados a respeito dos crioulos do Golfo da Guiné (3.1) e da(s) variedade(s) do Português encontrada(s) no país (cf. seção 3.2). Na seção 4 tecem-se as considerações finais.

\section{CONTEXTUALIZAÇÃO HISTÓRICA}

\subsection{A primeira colonização e o ciclo do açúcar}

É consensual entre as pesquisas inseridas na bibliografia deste estudo a afirmativa de que São Tomé, "o núcleo das três ilhas, foi a primeira a ser colonizada"

6 Em consonância com Ladhams (2007), Bandeira (2017: 117) sugere que os primeiros escravos “nem sempre eram edo e, por conseguinte, não falavam necessariamente” línguas edoides. Sob o domínio do Reino de Benin, encontravam-se grupos etnolinguísticos diferentes: haveria à época uma região ocupada pelo itsekiri, falantes de uma língua ioruboide, em conjunto com o porto de Ughoton e o Rio de Forcados. Ademais, “os mercadores de escravos podem ter sequestrado mão-de-obra fora da região linguística do Delta do Niger” (BANDEIRA, 2017: 117). Sendo assim, embora os dados linguísticos fortaleçam a hipótese de predomínio edoide, o ijoide também não deve ser descartado (cf. HAGEMEIJER, 2011).

7 Tradução de "at less than 10 percent of the overall lexicon, is primarily derived from Edo, the language of the old kingdom of Benin in Nigeria, and Kikongo, a western Banto language cluster spoken in the Congo and northern Angola”. 
(FERRAZ, 1979: 9). A ilha estaria desabitada, quando ocorreu uma tentativa fracassada de povoá-la em 1486. Outras expedições aconteceram ${ }^{8}$, mas apenas em 1493, um grande contingente de colonos migra de Portugal. Trata-se do ano da nomeação de Álvaro de Caminha como capitão-donatário, cargo mantido até 1505. Logo, encontrar-se-iam, ali, além de uma maioria de escravos, brancos a serviço da coroa portuguesa ou do comércio com a região da Guiné (BRÁSIO, 1953 apud BANDEIRA, 2017: 115).

Dados históricos e linguísticos comprovam relações entre Portugal e o Reino de Benin, entre os séculos XV e XVI, indicando que “a primeira colonização em São Tomé recorreu predominantemente, se não exclusivamente, à importação de escravos do Delta do Níger"9 (atual Nigéria). Associaram-se a eles muitos degredados encaminhados para lá, após cometerem crimes em Portugal. Do mesmo país, teriam vindo, ainda, em 1493, 2.000 crianças judias para se converterem ao catolicismo, depois de os pais serem expulsos da Espanha (cf. FERRAZ, 1979: 16; HAGEMEIJER, 2011 a: 113; BANDEIRA, 2017: 115). No entanto, grande parte faleceu pela insalubridade das embarcações ou por doenças adquiridas na chegada, restando, em 1506, cerca de 600 meninos e meninas ${ }^{10}$ (cf. BRASIO, 1953: 33-45 apud BANDEIRA, 2017: 115).

A primeira colonização parece ter estreitado o relacionamento entre europeus e africanos, se comparadas as fases da trajetória sociolinguística da ilha. A convivência mais intensa entre portugueses e escravos com suas respectivas línguas maternas (edoides e bantas, dentre as quais se destacam variedades do Quicongo e Quimbundo), no fim do século XV e nos primórdios do XVI, teria implicado uma aproximação dos subalternos ao código linguístico utilizado pelos

8 De acordo com Caldeira (2008: 50), em meio a doenças contagiosas comuns na Europa como a cólera e a febre tifoide, "a malária (...) pelo seu efeito dizimador, criará a ideia das ilhas de São Tomé e Príncipe como "cemitério de europeus", afastando potenciais candidatos à fixação no arquipélago e, correlativamente, facilitando a africanização do território. De facto, as populações que crescem nas zonas endémicas (...) desenvolvem anticorpos que lhes permitem ganhar uma relativa imunidade (...), o que de todo não acontecia com europeus acabados de desembarcar".

9 Tradução de "the early settlement on S. Tome relied predominantly, if not exclusively, on slave imports from the Niger Delta".

10 Pautado em um manuscrito de Valentim Fernandes, Sousa (1990 apud HAGEMEIJER, 2011) ressalta que havia, em 1506, na ilha de São Tomé, 1.000 moradores de residência fixa (europeus principalmente portugueses), 2.000 escravos permanentes e cerca de 5.000 ou 6.000 escravos transitórios. Entre os primeiros encontram-se, uma maioria de degredados, mas também membros do clero, soldados, outros homens, mulheres livres, e possivelmente também um grande número de órfãos judeus de Sevile, que deviam ter menos de 8 anos de idade quando chegaram em 1493. 
colonos (cf. HAGEMEIJER, 2009: 2). Complementando essa perspectiva, Clements (2000: 187) sugere a existência entre os últimos de "uma consciência alargada de foreigner talk" do idioma, ao alegar:

a gente daquela época conhecia estratégias de simplificação da sua própria língua, conhecimento que vinha dos portugueses e a grande quantidade de estrangeiros que tinham vindo para Portugal para repovoar a terra conquistada aos mouros pelo exercício cristão.(...) Nas cidades (...) da costa (Lisboa, Porto) existiam provavelmente uma ou mais variedades simplificadas do português que se deveriam ter formado e utilizado entre marinheiros e comerciantes. Essas variedades coexistiam com outras variedades linguísticas que se empregavam na comunicação, como por exemplo a língua franca.

Da necessidade iminente de diálogo entre colonos, falantes da língua portuguesa, e colonizados, em geral utentes de línguas africanas, teria resultado uma variedade pidgin e as diversas estratégias de simplificação certamente interferiram na sua formação (CLEMENTS, 2000: 187).

Acrescem-se a esses aspectos, as políticas de povoamento. Segundo Cortesão (1968: 33), havia desde o princípio, um decreto estabelecendo a doação de uma mulher escrava para cada condenado exilado. Anos depois, o rei Manuel determina a liberdade delas e dos descendentes e surgem os chamados "filhos da terra" ou "forros", uma classe composta por moradores de São Tomé, alguns, inclusive, mais abastados e poderosos, detentores de muitos subordinados (ANÔNIMO, 1550: 52; apud BANDEIRA, 2017: 118). Para Hagemeijer (2009: 4), é plausível a participação dessa comunidade "na origem e consolidação da nova língua que se falava na ilha.

A ausência de "uma atividade econômica de envergadura" e poucos povoadores tornavam a mão-de-obra essencialmente africana nas mais variadas tarefas (rurais, domésticas e de obras - cf. HAGEMEIJER, 2009: 2). Dividiam-se, pois, os cativos em dois estratos principais: os escravos de casa, com morada permanente na ilha; e os escravos de resgate, sequestrados de regiões do litoral africano e vendidos como mercadoria (cf. HAGEMEIJER, 1999; HLIBOWICKA-WEGLARZ, 2012; BANDEIRA, 2017). Aparentemente, o status local daqueles também interferiria na formação da língua emergente e boa parte dos demais ${ }^{11}$ seria reexportada para a feitoria da Mina como moedas de troca. A falta de embarcações estendia, contudo, a estada dos resgatados para além dos cinquenta dias es-

11 De acordo com Hlibowicka-Weglarz (2012: 178 apud BANDEIRA, 2017: 116), apenas uma pequena parcela dos escravos de resgate permanecia na ilha para pagar os soldos aos primeiros colonizadores. 
timados. Por isso, "passavam muitos meses em São Tomé, trabalhando como mão-de-obra temporária nas plantações e, participando, de certo modo, do processo de crioulização" (BANDEIRA, 2017: 116).

A partir de 1500, os portugueses garantem direitos sobre os cativos. O poderio exclusivo só foi atingido, contudo, em 1515, quando São Tomé se tornou um importante entreposto de escravos destinados a trabalhar nas plantações de açúcar e a "força motriz" ("driving force") das ilhas do Golfo da Guiné (cf. HAGEMEIJER; ZAMORA, 2016: 195).

Há relatos sobre plantações em São Tomé, desde os decretos de 1485, embora o ciclo econômico de cultivo do açúcar tenha se iniciado somente na década de 1510. Estendeu-se ao longo do século XVI, com ápice nos anos 1560, após a ilha ser reconhecida como exportadora, e declinou na primeira metade do século XVII, quando a maioria dos plantadores parte para o Brasil (cf. HAGEMEIJER, 2011 a; HAGEMEIJER; ZAMORA, 2016; HAGEMEIJER, no prelo). Aparentemente, aspectos como o "clima quente com chuvas abundantes, solo vulcânico, por conseguinte, fértil e (...) a disponibilidade do emprego de uma larga escala de cativos" (BANDEIRA, 2017: 119) favoreciam o plantio na região. As mesmas características devem, também, ter interferido no fracasso, pois, em relação ao fabrico, o excesso de humidade prejudicava "a secagem dos "blocos de açúcar". À qualidade superior do produto no novo mundo, somaram-se fatores como i) "a ameaça representada por outras nações europeias que começaram a navegar pelo Golfo da Guiné”; iii) "ataques ao sistema de plantação santomense por escravos fugidos"12 (HAGEMEIJER, no prelo); além iv) da "paritose que afectou as plantações (...) entre 1580 a 1595" (CALDEIRA, 2008: 50).

Durante a primeira colonização, a língua emergencial se complexificou e se efetivou como nativa, dando origem ao chamado PCGG: o Santomé ou Forro original, crioulo de base lexical portuguesa dominante na ilha até os dias atuais (HAGEMEIJER, no prelo). No mesmo período, parte da população migrou para povoar o Príncipe, estendendo-se a Ano Bom, na metade do século XVI. A necessidade de trabalhadores nas plantações sacarinas intensificou a exploração de mão-obra escrava. Congo e Angola se destacaram como áreas de resgate, e, rapidamente, declinou o poderio da Nigéria. Se "o predomínio de escravos Edo coincide com (...) o período de povoamento, que durou de 1485 até aproximadamente 1510/1520"13, os escravos Banto chegam em uma fase posterior à cristalização do

12 Tradução de "the threat posed by other European nations who started navigating the Gulf of Guinea, and the attacks on the Santomean plantation system by runaway slaves".

13 Tradução de "The predominance of Edo slaves overlaps (...) the homestead period, which lasted from 1485 until approximately 1510/1520”. 
PCGG (HAGEMEIJER, 2011: 112). Mais precisamente, "a mudança para uma sociedade de plantação corresponde à emergência e subsequente domínio de áreas Banto, primeiro do Congo e depois da Angola, no tráfico de escravos para São Tomé"14 (HAGEMEIJER, 2011: 112). Os novos cativos falavam, especialmente, línguas como Quicongo e o Quimbundo e aumentam em número nos primeiros anos da fase de plantação (anos 1510) com um impacto permanente:

Estudos genéticos realizados em São Tomé e Príncipe apresentam a mistura das populações que se tornaram os habitantes das ilhas ao longo dos séculos. Enquanto o genótipo europeu representa apenas 10\% do genótipo santomense, o genótipo africano constitui os outros $90 \%$ e pode ser mais especificado em dois componentes predominantes, um tipo oeste africano e um tipo banto, que confirmam o que é conhecido dos registros sobre o tráfico de escravos para as ilhas ${ }^{15}$ (cf. HAGEMEIJER; ZAMORA, 2016: 195-196).

No regime de plantação, "o crioulo ter-se-á rapidamente difundido para as roças, (...), tornando-se a língua-alvo dos escravos recém-chegados para efeitos de comunicação". (HAGEMEIJER, 2009: 4). Conforme se comentou na introdução deste capítulo, em decorrência, sobretudo, do fluxo migratório para outras regiões, iniciou-se a ramificação no espaço e no tempo do PCGG e

as variedades desta língua de contato foram levadas para as ilhas adjacentes do Príncipe, onde se tornou conhecida como Lung'iê 'língua da ilha' (Principense), e Ano Bom, onde evoluiu para o Fa d'ambô 'falar de Ano Bom', e também originou o Angolar (Ngola, Lunga Ngola), um crioulo quilombola usado em várias partes de São Tomé. ${ }^{16}$ (HAGEMEIJER, no prelo)

14 Tradução de "The shift towards a plantation Society corresponds to the emergence and subsequent dominance of Banto areas, first the Congo and then Angola, in the slave trade to Sao Tome”.

15 Tradução de "Genetic studies that were carried out on São Tomé and Príncipe show the admixture of the populations that became the inhabitants of the islands over the centuries. While the European genotype represents only some 10 percent of the São Tomé genotype, the African genotype makes up for the other 90 percent and can be further refined into two predominant components, a West-African and a Banto type, which confirms what is known from the records of the slave trade to the islands".

16 Tradução de "varieties of this contact language were taken to the neighboring islands of Príncipe, where it became known as Lung'Ie 'language of the island' (Principense), and Annobón, where it evolved into Fa d'Ambô 'speech of Annobón, and also originated Angolar (Ngola, Lunga Ngola), a maroon creole spoken in several parts of São Tomé”. 
No fim do século XVI, acentua-se a crise socioeconômica. Os cativos passaram a ser criados como animais: eram impedidos de semear para subsistência, foram separados de suas famílias e tiveram revogado o direito à liberdade dos filhos, até então decretado (cf. GARFIELD, 1992 apud BANDEIRA, 2017: 121). As fugas das roças para áreas distantes e a constituição de novas comunidades quilombolas, atestadas desde os últimos anos do século XV, intensificaram-se nesse momento. Colonos entraram em conflito com os escravos fugidos, no que Caldeira (2008: 50) denomina 'guerra do mato'. Na mesma época, a ilha foi invadida por piratas e sofreu uma série de atrocidades (cf. NEGREIROS, 1895). Finalmente, a capital foi saqueada por um ataque holandês (cf. FERRAZ, 1979: 19). Sobre o momento de plena decadência de São Tomé, Cortesão (1968: 42 apud BANDEIRA, 2017: 122) afirma que os fazendeiros com quem os combatentes angolares se preocupavam desde

1575 , e os comerciantes e os construtores de barcos, continuadamente perseguidos no mar, tinham a partir do final do século XVI abandonado a ilha em amplos números, a maioria deles ia para o Brasil. A indústria açucareira declinou notavelmente; dos muitos engenhos não mais que ruínas permaneciam; e parte da cidade antiga e densamente povoada agora estava deserta e destruída.

O êxodo europeu contribuiu para o desenvolvimento e para a difusão das línguas crioulas: com uma referência do Português cada vez mais limitada, a protolíngua parece buscar influências lexicais e fonológicas nas línguas de substrato africano (cf. FERRAZ, 1979: 19-20). Conforme se mencionou na seção 1, apesar de partilharem uma origem comum, hoje, a inteligibilidade entre tais crioulos é limitada, sobretudo "pela difusão do PCGG no tempo e no espaço e pelo subsequente desenvolvimento de cada variedade"17, através de novos contatos secundários (HAGEMEIJER, 2011: 112). Três séculos depois da descoberta, o país se torna, de novo, palco de uma série de mudanças socioeconômicas, cujos reflexos sociolinguísticos perduram até os dias atuais e serão comentados a seguir.

\subsection{A segunda colonização e os ciclos do café e do cacau}

No fim do século XVIII e primórdios do XIX, inauguram-se os respectivos ciclos do café e do cacau. Trata-se de um período de crise trabalhista, acentuado pela abolição da escravatura (1869) e pela formalização da condição jurídica dos libertos (1875). Uma vez livres, eles se negavam a trabalhar nas empresas agríco-

17 Tradução de "by the diffusion of the proto-GGC in time and space and the subsequent development of each variety”. 
las e a população local não supria a demanda de mão-de-obra. Na tentativa de garantir a força de trabalho, os europeus criaram a 'Curadoria Geral dos Indígenas', "solução, subjacente a uma revolução social e linguística inigualável nas ilhas através do recrutamento massivo de trabalhadores contratados (serviçais ou contratados) principalmente de outras colônias portuguesas em África"18 (HAGEMEIJER, no prelo).

O regime de contrato, instaurado em 1875 , representa um novo marco sociolinguístico, sobretudo pelo fluxo migratório de Cabo Verde, Angola, Moçambique, Benim e Gabão para São Tomé. Dados estatísticos de Nascimento (2000, apud GONÇALVES, 2016) atestam, a partir de então, um aumento demográfico notável, decorrente, em especial, da chegada de serviçais e de mais portugueses. Para além do PST e dos crioulos autóctones, suas línguas maternas (dentre as quais sobressaem o crioulo de Cabo Verde e variedades bantas como o Quimbundo e o Umbundo) ampliaram o multilinguismo. Segundo Hagemeijer (no prelo), "tal como os escravos africanos que chegaram em São Tomé e Príncipe no período inicial, no começo os trabalhadores contratados não falavam Português"19, mas, diferentemente do século XVI, nas senzalas das plantações, se mantinham segregados dos nativos em um ambiente exclusivo sociocultural e linguisticamente (cf. SEIBERT, 2014: 61). Trabalhando seis dias por semana, eles

tinham pelo menos alguma exposição ao Português, a língua dominante dos plantadores, cujo número aumentou desde o boom do café e do cacau. Os portugueses constituíam o principal grupo de proprietários, pois o governo santomense negou aos forros donos de terras o acesso aos trabalhadores contratados. (...) A população livre, em particular o grupo maior, os Forros, que viviam nas matas e vilas, fora dos novos sistemas coloniais, se mantem (deliberadamente) segregada dos serviçais, que eles consideram os 'novos escravos' e, portanto, de status inferior ${ }^{20}$ (HAGEMEIJER, no prelo).

18 Tradução de "a solution which underlies an unparalleled social and linguistic revolution on the islands through the massive recruitment of contract workers (serviçais or contratados) mainly from other Portuguese colonies in Africa".

19 Tradução de "Just like the African slaves that arrived in São Tomé e Príncipe in the earlier period, in the beginning the contract laborers didn't speak Portuguese”.

20 Tradução de "had at least some exposure to Portuguese, the dominant language of the planters, whose number had also gone up since the coffee and cocoa boom (...) the Portuguese constituted the main group of land owners, since the Santomean government denied Forro landowners access to contract workers $(,,$,$) the free population, in particular the largest group, the Forros, who lived$ in the forests and villages, i.e. outside the new colonial system, kept (deliberately) segregated from the contract laborers, which they considered the 'new slaves' and therefore of lower status". 
O Português tornou-se a referência naquele ambiente e "a L2 que os contratados começariam tipicamente a adotar" ${ }^{21}$. Surgiu, portanto, a variedade dos Tongas, fruto do contato entre as línguas maternas dos recém-chegados e aquela empregada nas roças. De acordo com Gonçalves (2016: 25), é provável que suas múltiplas formas "tenham emergido em função das idiossincrasias das diferentes roças em que eram faladas". Para Lopes; Baxter (2011a: 2), as variedades foram adquiridas "no trabalho em São Tomé, principalmente a partir de modelos de português L2 falados por trabalhadores colegas e, indiretamente, do português L1 dos administradores". Devido ao acesso limitado da maioria dos habitantes à língua e à "existência de poucas escolas primárias para a população crioula"22, adotam-se medidas como o decreto de 1878, que exige dos plantadores a disponibilização "de educação para seus funcionários e para os filhos deles", (HAGEMEIJER, no prelo). Representam, entretanto, "apenas uma gota no oceano e não refletem uma política linguística consistente pró-Português”23 (HAGEMEIJER, no prelo).

Conforme será reiterado na seção 3.2, a transição da Língua Portuguesa de L2 para L1 é um fenômeno subsequente à emancipação, quando o idioma é escolhido como língua oficial exclusiva, por já possuir uma norma padrão e ajudar a garantir a unidade nacional em meio à diversidade etnolinguística. Rapidamente, "deixou de ser a língua da elite e dos domínios mais altos ou formais, se tornando a língua de todos os contextos comunicativos e a L1 da maioria dos habitantes do país" 24 . Dentre os fatores influentes na mudança estão: i) o direito universal à educação (em Português); ii) a mobilidade social promovida pelo fim da era colonial; iii) o maior contato com meios de comunicação (rádio e televisão); e iv) a ausência de políticas linguísticas pró-crioulas (cf. GONÇALVES; HAGEMEIJER, 2015: 91). Por conta de todas as consequências da independência, não resta "muito do português dos tongas, mas o seu legado linguístico contribuiu para o que é hoje a variedade do português de São Tomé e Príncipe." (GONÇALVES; HAGEMEIJER, 2015: 90).

As seções futuras concentram-se no caráter plurilíngue da ilha, abordando tanto a evolução do PCGG nos quatro sistemas autóctones, quanto a disseminação do PST como língua veicular.

21 Tradução de "the L2 that the contract laborers would typically start to adopt".

22 Tradução de "the existence of few primary schools for the creole population".

${ }^{23}$ Tradução de "just a drop in the ocean and do not reflect a consistent pro-Portuguese language policy".

24 Tradução de "ceased to be the language of the elite and of the high or formal domains, becoming the language of all communicative contexts and the L1 of the majority of the country's inhabitants". 


\section{O MULTILINGUISMO EM SÃO TOMÉ E PRÍNCIPE}

\subsection{Os Crioulos do Golfo da Guiné}

\section{a) O Forro ou Santome}

Como se comentou na seção 2.1, a gênese do Santome, também chamado de Forro, remete à constituição de uma nova sociedade. Trata-se de um estrato social originalmente composto pelos primeiros escravos libertos após os decretos de Dom Manuel, em 1515 e 1517. Adquirindo direitos e poderes próprios, tal comunidade teria interferido, não só na origem, mas também na consolidação da nova variedade que, aos poucos, se expandiu pela sociedade colonial emergente (cf. HAGEMEIJER, 2009: 5). Mais que o produto do contato entre o Português (superstrato) e línguas Edo (substrato), o Santome ascendeu como uma língua de resistência e identidade social, durante a fase de habitação. Nas palavras de Lorenzino (1996: 435 apud BANDEIRA, 2017: 128), seu prestígio justifica-se por representar os "mestiços que atingiram um influente status socioeconômico quando se converteram em proprietários de terras e escravos". Não se pode, porém, descartar a existência de

um certo nível de bilinguismo entre os forros integrantes das classes sociais mais altas e entre parte da população escrava que tinha frequente contato direto com os Portugueses, tais como os escravos de casa (opondo-se aos escravos de plantação) e as mulheres cativas e seus descendentes como resultado de concubinatos. ${ }^{25}$ (HAGEMEIJER, no prelo)

Faltam dados exatos da distribuição das línguas autóctones pela população na era colonial, pois os recenseamentos só começam a considerá-las, após a independência do país, em 12 de julho de 1975. Estudos defendem, todavia, o acesso limitado ao Português e o predomínio dos crioulos. Com base em alguns testemunhos da época, Gonçalves; Hagemeijer (2015: 90) concluem:

Pelo menos até finais do século XIX, as línguas crioulas dominam a paisagem linguística das ilhas. A utilização do português parece estar circunscrita aos contextos que requerem uma relação mais direta com o regime colonial, havendo, em princípio, poucos falantes nativos desta língua.

25 Tradução de "a certain degree of bilingualism among the Forros belonging to the higher social classes and among parts of the slave population which had frequent direct contact with the Portuguese, such as the house slaves (as opposed to the plantation slaves) and female slaves and their descendants as the result of concubinages". 
Em outras palavras, o contato com a língua do colonizador restringia-se aos santomenses mais escolarizados, integrantes ou aspirantes à elite urbana. Por outro lado, para a população analfabeta, residente nas áreas periurbanas e rurais, os crioulos representavam as "línguas de comunicação quotidiana" (cf. MATA, 2010: 17). Nesse cenário, a variedade dos alforriados, adquiriu um status social privilegiado e constituiu, desde o século XVI, a língua-alvo dos escravos recém-chegados.

A comercialização do açúcar aumenta a demanda por mão-de-obra e, para além da zona de Benim, a ilha recebeu escravos do Congo e de Angola, falantes de línguas banto, como o Quicongo e o Quimbundo. Pautado em indícios de que os quatro crioulos se estabilizaram até 1520, quando o Edo era mais representativo na população, Hagemeijer (2009: 16-17) adverte: "nestas condições, o quimbundo não deve ser considerado uma língua de substrato, um papel reservado ao Edo, mas sim uma língua de adstrato, sem efeito fundador”.

A primeira alusão à "Lengua de San Thomé” data do século XVII: em 1627, o Padre Alonso de Sandoval, recém-chegado na ilha, menciona sua existência. Em 1766, Gaspar Pinheiro da Câmara (apud HOLM, 1988) também a cita. No entanto, somente no século XIX, divulgam-se estudos sobre a temática: Schuchardt o faz em 1882 e em 1895, Negreiros publica, na Historia Ethnographica da Ilha de São Thomé, um capítulo a respeito (cf. HAGEMEIJER, 2000).

Segundo Neves; Ceita (2004 apud HAGEMEIJER, no prelo), no fim do século XVIII, os forros representavam $95 \%$ da população de escravos libertos $(30 \%$ da população total de São Tomé) e até o fim do século XIX, sua língua nativa se manteve como a mais falada na região. Com o regime de contrato e a independência, o domínio diminuiu rapidamente e cada vez menos é adquirida como L1. Em contrapartida, o Português, variedade mais prestigiada, se expandiu (cf. seções 2.2 e 3.2), tornando-se o idioma veicular da maioria da população urbana ${ }^{26}$. Entre os sistemas autóctones, contudo, preserva-se o status privilegiado do Santomé. No interior do país, é muito frequente, associado à tradições e canções do grupo Forro. Dessa forma, atualmente, seu uso sucede o português: $36 \%$ (62.707) dos 173.015 habitantes do país, declaram falá-lo (RGPH, 2012).

\section{b) O Angolar}

No que remete à formação da comunidade angolar, três hipóteses competem. Segundo Seibert (2004), a primeira delas foi publicada no início do século

26 De acordo com o Factbook, (2009 apud BANDEIRA, 2017: 128), estima-se que 61\% da população santomense residam nas áreas urbanas, ao passo que 39\% se concentrem nas áreas rurais do país. 
XVIII e sugere serem sobreviventes de um naufrágio que acometeu um navio de escravos trazidos de Angola, no século XVI. A segunda defende que São Tomé não era desabitada quando os portugueses chegaram, isto é, a comunidade angolar original corresponderia aos habitantes autóctones da ilha. A terceira possibilidade, enfim, aponta a fuga de escravos para áreas até então desconhecidas. Esses fugitivos teriam formado o primeiro grupo, ampliado nos séculos XVI e XVII, após receber outros advindos das roças e das cidades com propósitos semelhantes.

Embora a hipótese de fuga dos cimarrones (cf. SEIBERT, 2004) ou quilombolas (cf. BANDEIRA, 2017) seja a mais recente, muitas evidências linguísticas e históricas parecem corroborá-la. Para Ferraz (1979), trata-se da possibilidade mais plausível, pois estudos comparativos comprovam a proximidade entre Angolar, Forro e Lung'ie. Há evidências de que os angolares falavam uma língua de base portuguesa e não banto, apesar de não se descartar uma possível aculturação histórico-linguística. Partindo de tal pressuposto, o autor questiona: como se justificaria a influência se estivessem isolados do restante da população, sendo sobreviventes de um naufrágio ou os primeiros habitantes do país? A necessidade de estudos mais específicos para infirmar ou confirmar as outras proposições tem promovido, portanto, a tese de que seriam escravos fugidos depois da formação do PCGG, cuja língua apresenta traços dessa variedade comum com especificidades derivadas do isolamento posterior.

Corroborando a perspectiva de Ferraz (1979), diversos autores ressaltam a existência de documentos históricos descrevendo a recorrência, à época, de evasões de escravos para o interior da ilha. Em 1499, Álvaro de Caminha comenta essas saídas para áreas campestres mais afastadas da capital (cf. ALBUQUERQUE, 1989 apud SEIBERT, 2004: 55). Migravam para espaços montanhosos e de difícil acesso, cansados dos maus tratos sofridos, das péssimas condições de trabalho oferecidas, da escassez de alimentos e do cerceamento à liberdade. Segundo Dias; Diniz (1988 apud BANDEIRA, 2017: 134), tal ambiente favoreceu a construção de quilombos e, durante os séculos XVII e XVIII, a inacessibilidade e os declínios demográfico e econômico garantiram relativo isolamento até a última parte do século seguinte.

Complementando tal ponto de vista, Bandeira (2017: 135) adverte:

não se pode afirmar que os quilombolas viviam em isolamento completo. Os assaltos à capital somados ao sequestro de mulheres das fazendas evidenciam que falantes de angolar tiveram contato com falantes de santome, o que viabilizou a troca de elementos linguísticos entre ambas as línguas.

Segundo a autora, há relatos de ataques de escravos à cidade (cf. HENRIQUES, 2000: 116) e de fazendas abandonadas pelos colonos após ameaças de 
foragidos (cf. SANTOS, 1996: 81). Nas zonas oeste e sul de São Tomé, mais próximas dos quilombolas, mesmo as expedições militares não garantiam a reconquista dos colonos (cf. CALDEIRA, 2004: 113). Em 1693, inclusive, o capitão do mato, Mateus Pires, comandou a chamada pacificação, uma última tentativa infrutífera de controlar os fugitivos sequestradores de mulheres na capital e nas plantações. De acordo com Almeida (1962: 10), desde então, não se encontram mais evidências de invasões aos espaços dos foragidos, sob pena de morte.

Hoje, os angolares distribuem-se em comunidades situadas no litoral, tanto no distrito de Caué, entre Ribeira Afonso e Porto Alegre, quanto no distrito de Lembá, entre Neves e Bindá. Mais próximos de São Tomé, há, ainda, pequenos grupos de falantes na Praia Melão, Pantufo e São João da Vargem (cf. CEITA, 1991 apud BANDEIRA, 2017: 135). Resultados do último censo estimam que 6\% (11.377) da população total do país (173.015) falem esse crioulo (RGPH, 2012). Com base nesses números, Hagemeijer (no prelo), afirma

A comunidade Angolar, que é tradicionalmente vista como um grupo mais homogêneo, também está sofrendo hoje um impacto massivo do Português, mas foi exposta previamente ao Forro, devido a sua difusão ao longo das áreas costeiras (...). Mesmo em seus redutos tradicionais, no distrito de Cauê, quase $100 \%$ da população afirma falar o Português, enquanto o Angolar é falado apenas por aproximadamente $50 \%$ nesta região. (...) é na faixa etária de 20 a 24 anos que mais de $50 \%$ ainda falam o Angolar (RGPH, 2012). Note-se, ainda, que os falantes do Angolar estão espalhados proporcionalmente por todos os distritos, exceto Lobata e Príncipe, onde seus números são menores, o que também contribui para o comprometimento desta língua. ${ }^{27}$

\section{c) O Lung'ie ou língua do Príncipe}

Pouco depois de aportarem em São Tomé, também na década de 1470, os portugueses chegam ao Príncipe (cf. seção 1). O nome original da Ilha, Santo Antão, mais tarde foi alterado para o atual em homenagem ao Príncipe Perfeito,

27 Tradução de "the Angolar community, which is traditionally seen as a more homogenous group, is nowadays also undergoing the massive impact of Portuguese, but had previously already been exposed to Forro due to their spread along (...) coastal areas. Even within their traditional stronghold, the district of Caué, almost $100 \%$ of the population claims to speak Portuguese, whereas Angolar is only spoken by roughly 50\% in this region. (...) it is from the age group of 20-24 on that over 50\% still speaks Angolar (RGPH, 2014). Note further that the Angolar speakers are spread out quite proportionately over all the districts, except for Lobata and Príncipe, where their numbers are lower, which also contributes to the endangerment of this language.”. 
Dom João. Em 1500, trinta anos após a chegada dos colonos, o território é doado por decreto real e se inicia o processo de colonização (cf. HENRIQUES, 2000; MAURER, 2009 apud BANDEIRA, 2017: 129), quando o PCGG, já constituído, teria sido levado para lá. Distante e isolada do restante do arquipélago, a língua-mãe estabelece contatos com outras variedades trazidas por novos escravos e, paulatinamente, se desenvolve a língua do Príncipe ou Lung'ie.

O isolamento parece implicar reflexos importantes: se comparado aos demais crioulos do Golfo da Guiné, no Lung’ie, haveria "mais léxico de origem edo e (...) aspectos fonológicos edóides, exclusivos da área onde essas línguas eram faladas" (BANDEIRA, 2017: 130). Em outras palavras, nesse sistema, a influência linguística do Delta do Níger se destaca, por i) representar a ramificação mais antiga do proto-crioulo do Golfo da Guiné; ii) ter sido menos afetada pelo ciclo de plantação e pela influência da força de trabalho banto dele decorrente; e iii) ter garantido, entre 1514 e 1518, o monopólio do comércio português com o Reino de Benim, preservando a ligação com o Delta do Níger (cf. HAGEMEIJER, 2011 a: 114).

Por volta de 1900, a população começa a declinar: a ilha do Príncipe sofre uma epidemia de tripanossomíase (doença do sono) e apenas 300 pessoas sobrevivem. Em virtude do impacto demográfico significativo e da necessidade de mão-de-obra, importaram-se trabalhadores contratados de diferentes áreas, como Angola, Moçambique, São Tomé e Cabo Verde (cf. MAURER, 2009).

Tendo em vista fatores como a quantidade de crianças que adquirem a língua-alvo como materna; a atitude da população perante a língua; e o impacto de outras línguas em potencial ou real competição (cf. CRYSTAL, 2000 apud BANDEIRA, 2017: 131), pode-se dizer que, atualmente, a língua do Príncipe está em risco de extinção. Com base nesses parâmetros, Crystal (2000) sugere três níveis de vitalidade linguística: seguro, ameaçado e extinto. ${ }^{28}$ Sob os critérios do autor, o Lung'ie estaria ameaçado, por conta da escassez de falantes (crianças) que o adotam como L1 e do "nível de impacto de outras (...), como o português, língua oficial e mais utilizada em todas as esferas sociais, e o kabuverdianu, haja vista que há muitos falantes descendentes dos trabalhadores contratados que chegaram na ilha no final do século XIX e começo do XX” (BANDEIRA, 2017: 131-132).

Para Maurer (2009: 3-4) o processo de extinção decorre: i) da "epidemia da doença do sono, cuja consequência foi a de que os falantes nativos do lung'ie foram rapidamente superados em números pelos trabalhadores contratados"; ii) da

28 A depender das escalas adotadas para determinar a vitalidade de uma língua, níveis diferentes podem ser encontrados. Nas escalas da UNESCO e dos linguistas Joshua Fishman e Paul Lewis, apresentam-se, 6, 8 e 13 níveis diferentes de extinção, respectivamente. 
falta de transmissão da língua "para os mais jovens por três ou quatro gerações"; e iii) de nenhuma estratégia ter sido adotada, anteriormente, na tentativa de promover o acesso dos imigrantes, sobretudo de Cabo Verde, a ela. Esses e outros fatores conduziram a uma maior difusão do kaboverdianu, depois de variedades regionais do Português e do Forro.

O último censo aponta cerca de 1.753 sobreviventes da comunidade, superando claramente os números apresentados em outras fontes: enquanto Maurer (2009: 3) afirma haver apenas 20 falantes ativos, Agostinho (2015) defende a existência de cerca de 200 utentes, sendo a maioria idosos bilíngues cuja fluência é variável. Segundo Hagemeijer (no prelo), trata-se de "estimativas (...) baseadas exclusivamente na situação linguística do Príncipe. Para esta ilha, o censo de 2012 considera 525 falantes, ao passo que os 1.228 restantes foram contados em São Tomé (a maioria em Água Grande, o distrito da Capital)"29. Ademais, "a aparente superestimação do número de falantes pode estar parcialmente relacionada a atitude linguística e não apenas ao uso da linguagem. ${ }^{30}$

\section{d) O Fa d'ambô ou falar de Ano Bom}

Como foi esclarecido na seção 2, o Fa d'ambô (ou falar de Ano Bom) é uma das línguas filhas do protocrioulo do Golfo da Guiné, fruto da migração para Ano Bom, uma das províncias da Guiné Equatorial, situada ao sudoeste de São Tomé. A ausência de evidências sobre a data exata da descoberta impede o consenso entre os teóricos, mas, em consonância com Caldeira (2010 apud HAGEMEIJER; ZAMORA 2016: 195), parece plausível situar o evento entre 1483 e 1501, no primeiro dia do ano, devido à tradição portuguesa de batizar áreas encontradas de acordo com o calendário. Em 1503, Jorge de Melo é nomeado capitão donatário e realiza um povoamento pioneiro também no começo do século XVI. Até pelo menos 1518, a ilha atuou como entreposto de escravos, e documentos comprovam a existência de tráfico marítimo ali ainda nos anos 1530, quando foi abandonada (cf. HAGEMEIJER; ZAMORA, 2016: 196). A colonização permanente deve ter ocorrido, enfim, por volta de 1543 e 1565, respectivos momentos dos registros de que i) a região estava deserta; e ii) fora habitada por um homem branco e alguns escravos plantadores de algodão (cf. CALDEIRA, 2010). O atraso seria decorrente de fatores como a "pequena extensão territorial (...), o relevo montanhoso que deixava poucas áreas férteis cultiváveis, (...) a falta de

29 Tradução de "Estimates (...) based exclusively on the language situation on Príncipe. For this island, the 2012 census counted 525 speakers, whereas the remaining 1,228 were counted on São Tomé (most of which in Água Grande, the district of the capital).

30 Tradução de "The apparent overestimation of the number of (active) Lung'Ie speakers might be partly related to language attitude and not just language use". 
ancoradouros seguros, sua posição longe das rotas comerciais portuguesas e (...) a forte concorrência com a ilha de São Tomé” (BANDEIRA, 2017: 136).

Face às dificuldades de se adotar um regime de produção agroindustrial, Portugal aderiu à partilha. Nela, o capitão donatário delegava funções ao clero local ou aos comerciantes de escravos (cf. CALDEIRA, 2010 apud HAGEMEIJER; ZAMORA, 2016: 196), dentre as quais se destacava uma importante fonte de renda: "a entrega de uma quantidade de algodão, às vezes, já tecido em faixas" (BANDEIRA, 2017: 136). Mesmo detendo o controle, a presença europeia na região era mínima, restringindo-se, por um longo período, ao representante do capitão-donatário, à guarda pessoal e ao feitor. A maioria da população era, assim, composta por escravos inicialmente trazidos “de São Tomé e (...) do Príncipe, ou (...) diretamente do continente africano, em particular do Congo e da Angola"31 (HAGEMEIJER; ZAMORA, 2016: 196). Nesse cenário, “o crioulo levado a Ano Bom, durante o pico da economia de plantação, pode ter sido uma forma do Proto-crioulo do Golfo da Guiné (= Santomense) que já tinha sofrido influência do estrato Banto Ocidental"32 (HAGEMEIJER, 2011 a: 114).

Reforçam a hipótese de uma origem santomense evidências da migração de falantes de uma língua dominante ou mesmo nativa para Ano Bom no fim do século XVI e início do XVII (cf. HAGEMEIJER; ZAMORA, 2016: 199-200). Em 3 de novembro de 1770, o capitão donatário de São Tomé e Príncipe, após acompanhar Antônio Luís Monteiro e Gregório Martins das Neves em uma viagem a Ano Bom, escreve uma carta em que relata a semelhança entre sua língua local e aquela falada pelos habitantes da ilha. Tal conexão é reafirmada em Matos (1842: 107 apud HAGEMEIJER; ZAMORA, 2016: 199), ao expor que "[...] o dialecto (...) de Anno Bom é o mesmo que o de S. Thomé, mas com uma pronunciação gutural semelhante a dos Árabes"33.

31 Tradução de "from São Tomé, and (...) also from Príncipe, or (...) directly from the African mainland, in particular the Congo and Angola".

32 Tradução de "the creole taken to Annobon, during the peak of the plantation economy, must have been a form of the proto-GGC (= ST) that had already undergone influence from the western Banto layer.”

33 Embora a analogia entre as línguas autóctones do Golfo da Guiné seja antiga, os primeiros estudos sobre crioulos surgem no fim do século XIX e se intensificam ao longo do XX. Em um trabalho pioneiro sobre a relação entre o Fa d'ambô e o Santome, Schuchardt (1888) comprova a gênese daquele nesse. Em meados do século XX, Barrena (1957) apresenta informações estruturais sobre a língua, em uma gramática póstuma. Desde então, vários estudos têm ampliado o conhecimento sobre o falar em foco (cf. VALKHOFF, 1966; GRANDA, 1985, 1986; FERRAZ, 1979; POST, 1998; ZAMORA, 2009, 2010; SILVEIRA, 2013; HAGEMEIJER; ZAMORA, 2016). 
Distante dos europeus, "o contato [da população anobonense] com o mundo exterior limitava-se ao fluxo de navios em busca de água doce e de mantimentos" 34 (HAGEMEIJER; ZAMORA, 2016: 196). Na passagem dos séculos XVII e XVIII, se extingue, pois o último representante português deixa a ilha, expulso ou morto (cf. CALDEIRA, 2008: 3). Consequentemente, por quase duzentos anos, todos os imigrantes foram impedidos de lá entrar, garantindo a liberdade e o isolamento da população de Ano Bom. Sem o "input português" e o "afluxo de novos escravos", a língua evoluiu livremente (BANDEIRA, 2017: 136), classificando-o como um crioulo fundamental para a compreensão da formação e evolução das demais línguas autóctones de base portuguesa, não só no Golfo da Guiné, mas também em outras áreas do Atlântico.

Em 1778, pelo Tratado de El Pardo, Portugal cede o Rio Muni e as ilhas de Ano Bom e Fernando Po à Espanha. Nesse capítulo de sua história,

a conexão com São Tomé se torna uma característica do passado e seu destino seria agora decidido por Santa Isabel (Malabo, a capital de Fernando Po (Bioko). No entanto, a nova conexão foi apenas ativada no fim do século XIX, pela chegada da missão Claretiana na ilha ${ }^{35}$ (HAGEMEIJER; ZAMORA, 2016: 193).

Segundo Hagemeijer; Zamora (2016: 202), atualmente, há cerca de 5.600 falantes de Fa d'ambô: 5.000 distribuídos por Ano Bom, Bioko e Malabo, na Guiné Equatorial; e 600 pela diáspora, a maioria na Espanha. Em Ano Bom, estimativas apontam uma comunidade linguística cujo número varia entre 2.000 (Ethnologue) e 3.000 (Zamora, 2009) utentes; já em Bioko, grande parte concentra-se nas proximidades da capital Malabo, estendendo-se a algumas vilas da costa e à cidade de Bata. Embora não existam registros oficiais,

pode-se seguramente assumir que o número de falantes de Fa d'ambô como L2 é muito pequeno. A língua não é usada como uma língua franca em outras comunidades na Guiné Equatorial e existe uma tendência para os anobonenses se casarem no âmbito de sua própria comunidade de fala. Além do Espanhol como língua oficial, utentes do Fa d'ambô, especialmente aqueles que vivem em Malabo, são usualmente falantes do Pichi também. As duas

34 Tradução de "contact with the outside world was limited to passing vessels in search of fresh water and supplies".

35 Tradução de “Annobón’s connection with São Tomé became a feature of the past and its destiny would now be decided from Santa Isabel (Malabo), the capital of Fernando Po (Bioko). However, (...) new connection was only activated at the end of the nineteenth century, through the arrival of the Claretian mission on the island”. 
linguagens têm deixado marcas no crioulo, que são essencialmente circunscritas ao domínio lexical ${ }^{36}$ (HAGEMEIJER; ZAMORA, 2016: 202).

Trata-se de uma das menores comunidades de fala da região da Guiné, cujos integrantes se distribuem por diferentes espaços. A língua é, porém, “transmitida entre gerações e goza de prestígio social entre seus falantes" 37 (HAGEMEIJER; ZAMORA, 2016: 202). A propagação e o prestígio parecem resultar de uma história de isolamento, legitimada na maior resistência às influências externas e "contribuem para um forte espírito de solidariedade e auto-identidade" 38 . Além disso, o difícil relacionamento entre a minoria anobonense e o grupo étnico dominante na região, o Fang, também "poderia ser considerado um fator que promove a identidade do grupo e a manutenção da linguagem" 39 (HAGEMEIJER; ZAMORA, 2016: 203).

De acordo com Granda (1985 apud HAGEMEIJER; ZAMORA, 2016: 203), até a independência da Guiné Equatorial, há pouca exposição do crioulo à linguagem oficial, pois o uso do espanhol limitava-se aos missionários e a alguns professores e oficiais. No início dos anos 1980, enquanto o conhecimento do espanhol começa a se difundir pelos homens adultos, mulheres e crianças preservam-se como monolíngues em Fa d'ambô. Ademais, como os homens mais jovens e de meia idade passam grande parte de seu tempo trabalhando em Bioko, usam o Pichi com seus pares. Em consonância com Post (1998), Hagemeijer; Zamora (2016: 203) afirmam que o Fa d'ambô é a língua nativa na ilha de Ano Bom, mas a maioria da população valoriza e fala o idioma oficial. Existe, no Bioko, um grupo de imigrantes (homens e mulheres jovens e de meia idade) aportados para estudar ou trabalhar, que só retornam à ilha em uma idade mais avançada, caracterizando-a como "um espaço para crianças e idosos. Além de sua língua nativa, o espanhol é a língua exclusiva usada na educação primária e secundária"40 (HAGEMEIJER; ZAMORA, 2016: 203). Assim, devido ao "maior isolamento e à

36 Tradução de "it can safely be assumed that the number of L2 Fa d'Ambô speakers is very low. The language is not used as a lingua franca by other speech communities in Equatorial Guinea and there is a tendency for Annobonese to marry within their own speech community. In addition to the official language Spanish, Fa d'Ambô speakers, especially those who live in Malabo, are usually Pichi speakers as well. Both these languages have left imprints on the creole, which are mostly restricted to the lexical domain".

37 Tradução de "transmitted across generations and enjoys social prestige among its speakers".

38 Tradução de "contributed to a strong spirit of solidarity and self-identity".

39 Tradução de "should be considered a factor that promotes group identity and language maintenance".

40 Tradução de "a place for children and the elderly. In addition to their native language, Spanish is the exclusive language used in primary and secondary education". 
idade da comunidade em Ano Bom, espera-se encontrar uma variedade mais conservadora ali”"41 (HAGEMEIJER; ZAMORA, 2016: 204).

Até o início dos anos 1990, o território permanece isolado, isento de influências midiáticas alheias, como rádio, televisão ou livros. Em contrapartida,

na capital Malabo, (...) falantes do Fa d'ambô se expõem a outras línguas, em particular ao espanhol e à língua franca Pichi, falada por alguns. Apesar da coexistência dessas línguas, (...) não houve variação significativa entre os falares de Ano Bom e Malabo devido à contínua migração entre os dois espaços $^{42}$ (HAGEMEIJER; ZAMORA, 2016: 203).

Vinte anos depois, esse cenário evolui: em 2010, Ano Bom inaugura um porto e um aeroporto e disponibiliza o acesso aos meios de comunicação midiáticos. Com base nessas mudanças, Hagemeijer; Zamora (2016: 203) salientam: "enquanto o Fa d'ambô não está incluído na lista de linguagens ameaçadas da UNESCO, os sinais de que existem pontos fracos na transmissão geracional (...) não podem ser desconsiderados." ${ }^{\text {"3 }}$ Atualmente, a língua está perdendo sua fluidez: existem crianças anobonenses que não falam o crioulo (cf. ZAMORA, 2010 apud HAGEMEIJER; ZAMORA, 2016: 204) e jovens em Malabo frequentemente usam o Pichi para se comunicarem (cf. HAGEMEIJER; ZAMORA, 2016: 204). Portanto,

a mudança para o Pichi, que é mais proeminente entre as gerações mais jovens (...) poderia ser identificada como a principal ameaça ao Fa d'ambô. Comparada ao espanhol, a língua franca formal, o Pichi prospera como língua franca informal, a língua das estradas, do comércio e mercados, afetando a estável diglossia que caracteriza a relação entre Fa d'ambô e o espanhol. O Pichi é o competidor direto do Fa d'ambô na esfera informal do Bioko $^{44}$ (HAGEMEIJER; ZAMORA, 2016: 204).

41 Tradução de "the more isolated and aged community on Annobón, the more conservative variety is expected to be found there".

42 Tradução de "in the capital Malabo, (...) Fa d'Ambô speakers were exposed to other languages, in particular to Spanish and to the lingua franca Pichi, spoken by many. Despite the coexistence of these languages, (...) there was no significant variation between Fa d'Ambô spoken on Annobón and in Malabo due to ongoing migration between both spaces".

43 Tradução de "While Fa d'Ambô is not included on the UNESCO list of endangered languages, the signs that there are weak spots in the generational transmission (...) should not be dismissed."

44 Tradução de "This shift to Pichi, which is more prominent among the younger generations (...) should be identified as the main threat to Fa d'Ambô. Compared to Spanish, the formal lingua franca, Pichi thrives as the informal lingua franca, the language of the streets, commerce, and markets, affecting the stable diglossia that characterizes the relation between 
Convive com tais línguas, na ilha de Ano Bom, uma variedade de discurso litúrgico baseada no Português (arcaico) (...) "que compreende elementos lexicais e gramaticais do português, do Fa d'ambô e provavelmente também umas poucas expressões do Latim"45 (HAGEMEIJER; ZAMORA, 2016: 200). A sobrevivência dessa "forma crioulizada do português" parece se justificar em uma forte tradição católica introduzida em São Tomé e estimulada pelo clero, cuja presença remete "ao desenvolvimento de um culto autossuficiente, transmitido pelos sacerdotes locais que atuam em paralelo às igrejas para satisfazer as necessidades espirituais da população"46 (HAGEMEIJER; ZAMORA, 2016: 201).

Em suma, apesar de se reconhecer que a relação entre o Fa d'ambô e a identidade anobonense contribui para a preservação do crioulo, fatores como ser "uma pequena comunidade linguística que se tornou mais dispersa, devido à (e) migração; a crescente exposição à língua franca Pichi; e a falta de suporte governamental" ${ }^{\prime 47}$ parecem colocá-lo em um crescente risco de extinção. Nas palavras de Hagemeijer; Zamora (2016: 206),

as permanentes emigração e exposição ao Pichi e ao Espanhol nos domínios baixo e alto, (...) reduzirão a participação de nativos, falantes competentes de Fa d'ambô e podem ultimamente levar a sua remodelação, por exemplo através da relexificação parcial, harmonização estrutural ou, na pior das hipóteses, à mudança linguística. ${ }^{48}$

\subsection{A língua companheira do império em São Tomé e Príncipe}

A expansão do Português para além de Portugal se inicia no ano de 1415, quando colonizadores se lançam ao mar e aportam em diferentes paragens com

Fa d'ambô (L) and Spanish (H). Pichi is Fa d'Ambô's direct competitor in the informal sphere on Bioko".

45 Tradução de "comprises lexical and grammatical elements of Portuguese, Fa d'Ambô, and arguably also a few Latin expressions".

46 Tradução de "to the development of a self-sufficient cult, transmitted by local priests who functioned in parallel to the church, in order to satisfy the spiritual needs of the population".

47 Tradução de "a small speech community that has become more scattered due to (e)migration; growing exposure to lingua franca Pichi; and the lack of any type of government support for language maintenance".

48 Tradução de "the ongoing (e)migration and exposure to Pichi and Spanish in the Low and High domains (...) will reduce the share of native, competent Fa d'Ambô speakers and may ultimately lead to the reshaping of $\mathrm{Fa}$ d'Ambô, for instance through partial relexification, structural convergence, or in a worst-case scenario, to language shift”. 
religião, cultura e, principalmente, idioma próprios. Pode-se dizer que a diacronia da língua, classificada como "companheira do império" desde Fernão de Barros e António de Nebrija, representa "a trajetória histórico-linguística de Portugal e das ex-colônias, uma história de dominação, de relações tensas, de violência exercida sobre o Outro" (AFONSO, 2009: 41).

Imbuído de uma função imperial, o Português se tornou um instrumento de submissão na relação colonizador-colonizado. No processo de expansão, era uma garantia da manutenção do império, pautada em uma ideologia de déficit, em que de um lado se tinha uma língua prestigiada, erudita, e de outro, línguas africanas inferiores, de tradição folclórica. Nesse contexto, os colonizados eram entendidos como povos não civilizados e

imperiosamente se lhes impunha romper com as milenárias estruturas mentais e sociais para se transferirem para outros planos de vida, o plano dos "assimilados", civilizados ou cidadãos, libertos das hierarquias e disciplinas tribais, passando a viver no estilo e costumes europeus, falando, lendo e escrevendo Português. (AFONSO, 2009: 41).

No processo de "civilização", as línguas autóctones eram, portanto, encaradas como línguas bastardas dos selvagens. Desprestigiados na comunicação em público, a tais sistemas costumava ser negado um lugar oficial na sociedade. Não podiam ser ensinados, exceto para facilitar a aprendizagem do Português pelas instituições missionárias. Entre 1921 e 1954, mesmo para essa finalidade, seu uso foi impedido, sendo novamente autorizado pelo Decreto-lei n. 39666 do Estatuto dos Indígenas Portugueses das Províncias da Guiné, Moçambique e Angola ${ }^{49}$. A respeito da supremacia europeia, Feytor Pinto (2001: 66) alega: "por repudiarem a aprendizagem de línguas africanas, os portugueses preferem recorrer a intérpretes que são escravos de senhores africanos, obrigados a aprender o Português". Além disso, "a primeira descrição portuguesa do funcionamento de uma língua africana" foi "publicada em 1697, mais de 250 anos dos primeiros contatos". (FEYTOR PINTO, 2001: 101).

Como se verifica, no imperialismo linguístico, garante-se a hegemonia do idioma dos colonos, inferiorizando as línguas africanas. O preconceito cultural aumenta quando se reconhece a exclusividade da língua portuguesa na atribuição de cidadania. De acordo com Ferreira (1989: 29),

O colonialismo é a negação da personalidade do Outro. Ele (...) nega e reprime a cultura autóctone e obriga à cultura metropolitana. Altera os hábitos sociais, intervém na culinária, no vestuário, no sistema agrícola, no re-

49 Cf. Diário do Governo, 20.5.1954 apud Feytor Pinto (2001: 89). 
gime de propriedade, na habitação, no sistema jurídico, na ordem social milenar estabelecida, impõe novos padrões de cultura e substitui a língua.

Trata-se de um regime essencialmente antropofágico, que "ao instalar-se em território alheio, (...) alimenta-se de uma necessidade: a devoração do Outro. Em todos os sentidos: político, cultural, ideológico, económico, religioso, linguístico” (FERREIRA, 1989: 31). Na visão dos portugueses, contudo, essas expedições eram entendidas como uma missão de salvar, através da cidadania e da religião, os povos selvagens, como ilustram as seguintes palavras de Rosa (1973: 61):

Estamos por aqui na calma insistência de quem cumpre uma predestinação, modelando homens e povos à nossa imagem e semelhança, criando neles novos conceitos de vida, erguendo suas almas e seus corpos e, arrancando-os da comum animalidade, gravando neles a consciência de um destino transcendente (...). Esta certeza que nos empolga, de sermos obreiros da História (...) dá-nos, a nós, portugueses, um estranho complexo de grandeza.

Sucedendo a política glotofágica, inicia-se um processo de mudança linguística. O Marquês de Pombal, em 1757 e 1758, determina o ensino da língua portuguesa no Brasil em detrimento da língua geral dos índios e, mais tarde, aquela se torna o principal idioma do país. Quadro semelhante se apresenta na África, quando o general Norton de Matos, governador de Angola entre 1921 e 1924, estabelece a extinção das línguas africanas, disseminando o Português, cujo ensino se tornou obrigatório em todas as missões.

Ao longo do século XIX, o sistema dos territórios já dominados passa a diferenciar a educação oficial, destinada à população urbana europeia, da educação missionária, concedida aos povos africanos rurais. Sustentando os interesses dos colonos europeus, às missões cabia transmitir a língua portuguesa aos africanos e limitar o uso das línguas africanas ao ensino religioso. Negava-se, dessa maneira, ao Outro o direito à identidade cultural, impondo-lhe valores entendidos como merecedores de imitação. Para Afonso (2009: 46), "arreigando o seu discurso no eurocentrismo, a colonização linguística de que são vítimas os povos colonizados, desemboca na institucionalização oficial, exclusiva e definitiva da língua portuguesa”.

Em São Tomé e Príncipe, as missões portuguesas começaram desde a fase de colonização, em 1493. Já no início desse processo, o ensino religioso se destaca na tentativa de europeizar os povos locais. No entanto, conforme se esclareceu nas seções precedentes, até a independência do país, o Forro preservava-se como língua dominante, seguido pelos demais sistemas autóctones. Ali, ao mesmo tempo em que a língua portuguesa desempenha um importante papel no Império, não há uma estratégia de difusão linguística e, uma vez declarada a independência, constata-se um alto índice de analfabetismo. Para Margarido (2000), o compor- 
tamento se justifica na necessidade de preservar a ignorância da população subalterna, na tentativa de limitar sua consciência crítica. Em consonância com essa perspectiva, Afonso (2009: 47) enfatiza a língua como agente específico de dominação, pois

permitiria a Portugal recuperar a sua "grandeza" consubstanciada já não numa submissão política dos demais países lusófonos, mas cultural, cabendo à variedade europeia o privilégio de continuar a gozar de estatuto hegemónico relativamente às variedades emergentes no ex-império colonial português em África. (...) A potência colonial contrariou, sensivelmente, a dinâmica cultural dos países dominados. As línguas autóctones tinham necessariamente que sofrer o efeito dessa dominação. Excluídas do ensino, proibidas de serem utilizadas, embora continuassem a ser faladas, o seu papel limitou-se, quase exclusivamente, à produção de obras orais, em alguns casos bem ricas e variadas. (...) Porém, o lugar de destaque, esse, estava reservado à língua portuguesa.

A supremacia europeia atribuiu às línguas crioulas um caráter pejorativo. Há relatos de famílias, que, por aspirarem à ascensão social, proibiam os filhos de se comunicarem nas variedades locais, usando, no ambiente familiar, formas do Português como L2 na construção da L1 das crianças nativas. A esse respeito, Mata (2010: 17) ratifica a recorrência na elite de sujeitos que não sabiam falar qualquer crioulo, mesmo nos contextos cuja resistência nacionalista é maior. Além disso, os integrantes da elite envergonhavam-se quando se viam forçados a falá-los. Nas palavras de Afonso (2009: 48), atualmente,

parece (...) reinar no espírito do filho-da-terra a ideia incutida pelo poder colonial de que o Crioulo e demais línguas nacionais são formas linguísticas bastardas, desprovidas de dignidade para serem utilizadas em espaços públicos e como tal devem circunscrever-se ao meio familiar e rural.

Em contrapartida, a língua portuguesa

Foi, efectivamente, a língua, companheira do império, embora essa companhia tenha sido partilhada com as demais línguas nacionais. (...) uma vez desmoronado o império (político), ela continua ainda a manter o seu estatuto hegemónico, (...) em regime de coexistência com as demais línguas locais.

Após a independência e as posteriores massificação do ensino e mobilidade social dela decorrente, intensifica-se o processo de mudança linguística em São Tomé e Príncipe. Havia uma língua portuguesa dominante, trazida pelo colonizador e escolhida pelos novos governantes como oficial. No entanto, como a grande maioria da população era (semi)analfabeta, o Português veicu- 
lar herdou traços dos crioulos e da variedade dos Tongas, alterando em muitos aspectos o sistema linguístico alvo (cf. AFONSO, 2009: 68). Assiste-se a uma transição em que a língua de maior prestígio, a segunda língua da elite urbana, expande-se a todos os contextos de comunicação, tornando-se L1 de uma parcela considerável da população. Verifica-se, ao mesmo tempo, "um aumento gradual da erosão linguística dos crioulos, um processo tipicamente associado a contextos de línguas em contato, caracterizado pela perda de competência linguística da L1, motivada pela primazia do uso da L2" (GONÇALVES, 2016: 26).

Atualmente, as elevadas taxas de falantes (nativos) do Português caracterizam São Tomé como "um caso único na África, onde o nível de nativização das antigas línguas coloniais é geralmente baixo" 50 (HAGEMEIJER, no prelo). Como asseguram Gonçalves; Hagemeijer (2015: 91),

a estigmatização dos crioulos, herdada no tempo colonial, não foi devidamente ultrapassada, impedindo, em definitivo, a construção de uma identidade (...) ligada às línguas crioulas. (...) São Tomé e Príncipe é hoje a ex-colônia portuguesa onde se registra o maior número de falantes nativos do português, o que significa também que todos os crioulos autóctones de São Tomé e Príncipe estão ameaçados.

Existem, todavia, diversos estatutos para a língua portuguesa ali. O Português Europeu é a língua oficial do país, a língua-alvo dos falantes. Ao mesmo tempo, a maioria da população fala um "português santomensizado". Tal variedade foi fortemente influenciada pelo Forro, língua materna de alguns e língua segunda de outros; e por outras línguas, como as faladas pelos contratados, atuantes nos processos históricos de aquisição da L2 e de nativização. Trata-se de "estatutos que ora remetem para uma função institucional e social que a língua cumpre junto da sociedade são-tomense no seu todo, ora para uma relação individual que com ela estabelece cada indivíduo dessa mesma sociedade" (AFONSO, 2009: 64).

Apresenta-se, pois, um processo de fossilização linguística, muito frequente em casos de contato ou aquisição de L2. Em uma situação de imersão, em que há o predomínio da norma aspirada pelo falante, a gramática manifestada alia o conhecimento da primeira língua aprendida a aspectos linguísticos mais universais. São realizações distintas do padrão, enraizadas de tal modo no discurso do falante, que dificilmente podem ser corrigidas. Ademais,

50 Tradução de "a unique case in Africa, where the degree of nativization of former colonial languages is generally low". 
Interiorizadas, tais estruturas poderão acompanhar o falante ao longo da sua vida, vindo a ser transmitidas pelos mesmos, enquanto agentes de socialização, aos filhos ou outros elementos com os quais interagem. (...) $\mathrm{Da}$ convivência com as línguas crioulas o Português sofre, quer a nível da oralidade, quer na escrita, uma grande influência destas línguas, resultando numa nova variedade. (AFONSO, 2009: 69)

Por conseguinte, qualquer estudo sobre o PST deve considerar ao menos duas variedades: o Português Europeu, a língua oficial padrão, "língua materna de uma parte diminuta da população e que para a grande maioria pode ser considerada língua segunda;" e o Português local, língua veicular, "um falar de características fonológicas e morfossintácticas próprias, cujos desvios em relação à norma são significativos, em que se assiste a uma tendência cada vez maior para a contaminação do código escrito pelo código oral" "51 (AFONSO, 2009: 70). No último tipo, enquadra-se o Português como língua materna da maioria da população: produto do contato com as línguas crioulas e, consequentemente, repleto de desvios à norma padrão, prevista na língua oficial.

Em suma, para além das variedades crioulas, a variação intrínseca à língua portuguesa em São Tomé contribui para o multilinguismo, haja vista a convivência de: i) uma "língua materna", de socialização da grande maioria dos falantes, o "falar são-tomense", "variante oral do português são-tomense (...) já ela eivada de interferências, a que se vão somando outras tantas no decurso da interacção social"; ii) uma "língua não materna" (alvo, oficial), que se pretende ensinar "geralmente na idade escolar", quando o falante entraria "em contacto relativamente efectivo com o Português" em um ambiente privilegiado, a escola; e iii) uma "língua de ensino", ministrada a crianças, a partir dos 6 anos de idade, geralmente, por professores santomenses, desprovidos do conhecimento necessário sobre a língua oficial, cujas competências linguísticas e comunicativas são limitadas (AFONSO, 2009: 71).

\section{CONSIDERAÇÕES FINAIS}

Um breve olhar sobre a trajetória do país revela, pois, os contributos i) da primeira colonização e do ciclo do açúcar, na formação dos crioulos do Golfo da

\footnotetext{
51 A interferência do código oral no escrito representa uma questão assaz complexa em diferentes locais onde a Língua Portuguesa é oficial. Análises sociolinguísticas defendem que, em países como Portugal e Brasil, falantes menos escolarizados e integrantes de classes sociais menos abastadas tendem a aproximar, de maneira mais explícita, os modelos de oralidade e escrita do Português. Trata-se de um comportamento que parece refletir carências educativas, como a ausência de livros e do contato com uma cultura de leitura, por exemplo.
} 
Guiné; e ii) da segunda, durante os ciclos do café e do cacau, para a maior disseminação do Português e para a mudança linguística dela decorrente (cf. GONÇALVES, 2016: 24). Em outras palavras,

São Tomé e Príncipe sofreu uma transformação linguística e sociolinguística a partir do último quartel do século XIX que se traduz (...) na hegemonia do português em detrimento das línguas crioulas autóctones. Esta transição histórica de (...) L2 para (...) L1 reflete-se nas características que hoje constituem o português de São Tomé. (GONÇALVES; HAGEMEIJER, 2015: 92)

Há evidências históricas de que as línguas autóctones eram as mais faladas pela população até o século XX, enquanto o uso do Português se limitava "à minoria de falantes nativamente portugueses e àqueles que tinham uma relação mais próxima com o poder colonial" 52 (HAGEMEIJER, no prelo). Conforme o supracitado, sua ascensão no interior do país se inicia, na transição entre os séculos XVIII e XIX, com os ciclos do café e do cacau, quando a variedade europeia se torna a referência no convívio entre trabalhadores contratados e fazendeiros. Desenvolve-se, então, o chamado "Português dos Tongas", fruto do contato entre línguas africanas dos serviçais e o Português utilizado nas roças. Depois da independência, em 1975, o Português se efetiva como língua oficial da nação santomense e se amplia o acesso à educação no idioma. Visando promoção social, muitos nativos já o empregavam no seio familiar e, aos poucos, assiste-se à transição da língua de L2 para L1 de grande parte da população. De acordo com o último censo realizado no ano de $2012,98 \%$ (170.223) da população total (173.015) declaravam-se utentes do idioma oficial. Em contrapartida, 36\% (62.707), $8 \%$ (14.654), 6\% (11.377) e 1\% (1.753) dos habitantes alegavam falar, respectivamente, o Forro, o Caboverdiano, o Angolar e o Lung'iê.

\section{REFERÊNCIAS}

AFONSO, H. L. Interferências linguísticas: um contributo para o ensino da língua portuguesa em S. Tomé e Príncipe. 2009. 184f. Dissertação (Mestrado em Língua Portuguesa) - Faculdade de Letras, Universidade de Lisboa, Lisboa, 2009.

AGOSTINHO, A. L. Fonologia e método pedagógico do Lung'ie. 2015. 425p. Tese (Doutorado em Filologia e Língua Portuguesa) - Faculdade de Letras, Universidade de São Paulo, São Paulo, 2015.

ALMEIDA, A. de. Da origem dos angolares habitantes da ilha de S. Tomé. Separata das Memórias, 1962. t. VIII.

52 Tradução de "restricted to the natively Portuguese-speaking minority and to those who had a close relation with the colonial power." 
BANDEIRA, M. Reconstrução fonológica e lexical do protocrioulo do Golfo da Guiné. 2017. 324f. Tese (Doutorado em Filologia e Língua Portuguesa) - Faculdade de Filosofia, Letras e Ciências Humanas, Universidade de São Paulo, São Paulo, 2017.

CALDEIRA, A. Rebelião e outras formas de resistência à escravatura na ilha São Tomé (séculos XVI a XVIII). Africana Studia, Porto: Universidade do Porto, v. 7, p. 101-136, 2004.

CALDEIRA, A. Variação e mudança no vocalismo do PB: perfil geo-sociolinguístico. In: CONGRESSO INTERNACIONAL DA ABRALIN, 8, 2013. Rio Grande do Norte. Comunicação.

CALDEIRA, A. Medo e religião popular na ilha de Ano Bom. Uma aproximação histórica (séculos XVI-XIX). Biblioteca Digital Camões, 2008. Disponível em: <http: //cvc. instituto-camoes.pteaarcoloquiocomunicacoes>. Acesso em: 20 maio 2017.

CALDEIRA, A. La leyenda de lodã, o de cómo rolando, compañero del emperador Carlomagno, defendió la isla de Annobón de una invasión terrible. Oráfrica, Revista de Oralidad Africana, Espanha, v. 6, p. 89-114, 2010.

CLEMENTS, J. C. Evidência para a existência de um pidgin português asiático. In: D'ANDRADE, E.; PEREIRA, D.; MOTA, M. A. (Eds.). Crioulos de base lexical portuguesa. Braga: Associação Portuguesa de Linguística, 2000.

CORTESÃO, J. Os portugueses em África. Lisboa: Portugália, 1968.

CRYSTAL, D. Language death. Cambridge: CUP, 2000.

FERRAZ, L. I. The creole of São Tomé. Johanesburgo: Witwatersrand University Press, 1979.

FERRAZ, L. I. Portuguese creoles of West Africa and Asia. In: GILBERT, G. G. (Ed.). Pidgin and creole languages: essays in memory of John E. Reinecke. Honolulu: University of Hawai Press, 1987. p. 337-360.

FERREIRA, M. Contextualização da língua portuguesa. In: FERREIRA, M. O Discurso no percurso africano. Lisboa: Plátano Editora, 1989. p. 311-318.

FEYTOR PINTO, P. Como pensamos a nossa lingua e as linguas dos outros. Lisboa: Editorial Estampa, 2001.

GONÇALVES, R. M. G. Propriedades de subcategorização verbal no Português de São Tomé. 2010. 151f. Dissertação (Mestrado em Linguística) - Faculdade de Letras, Universidade de Lisboa, Lisboa, 2010.

GONÇALVES, R. M. G. Construções ditransitivas no Português de São Tomé. 2016. 286f. Tese (Doutorado em Linguística) - Faculdade de Letras, Universidade de Lisboa, Lisboa, 2016.

GONÇALVES, R. M. G.; HAGEMEIJER, T. O Português num contexto multilingue: O caso de São Tomé e Príncipe. Revista Científica da Universidade Eduardo Mondlane, Moçambique, v. 1, n. 1, p. 87-107, 2015.

GRANDA, G. de. Estudios de linguistica afro-romanica. Valladolid: Universidad de Valladodid, 1985. 
GRANDA, G. de. Retenciones africanas en la fonética del criollo portugués de Annobón. Revista de Filología Románica, Madrid: Universidad Complutense Madrid, v. 4, p. 111-124, 1986.

HAGEMEIJER, T. As ilhas de Babel: a crioulização no Golfo da Guiné. Camões, Revista de letras e culturas lusófonas, Portugal, n. 6, p. 74-88, 1999.

HAGEMEIJER, T. Serial verb constructions in São-Tomense. 2000. Dissertação (Mestrado em Linguística) - Faculdade de Letras, Universidade de Lisboa, Lisboa, 2000.

HAGEMEIJER, T. Semi-lexicality and underspecification in serial verb constructions. In: CORVER, N.; van RIEMSDIJK, H. Semi-lexical heads. New York: De Gruyter, 2001. p. 415-451.

HAGEMEIJER, T. Clause structure in Santomé. 2007. Tese (Doutorado em Linguística) - Faculdade de Letras, Universidade de Lisboa, Lisboa, 2007.

HAGEMEIJER, T. Initial vowel agglutination in the Gulf of Guinea creoles. In: ABOL, E.; SMITH, N. (Eds.). Complex processes in new languages. Amsterdam/Filadélfia: John Benjamins Publishing Company, 2009 c. p. 29-50.

HAGEMEIJER, T. The Gulf of Guinea creoles: genetic and typological relations. Journal of Pidgin and Creole Languages, v. 26, n. 1, p. 111-154, 2011.

HAGEMEIJER, T. O Português em contacto em África. In: MARTINS, A. M.; CARRILHO, E. (Eds.). Manual de Linguística Portuguesa. Frankfurt, Leipzig: Deutsche nationalbibliothek, 2016. p. 43-67.

HAGEMEIJER, T. S. Tomé e Príncipe: labirinto e laboratório de línguas. In: SEIBERT, G. Arquipélagos Atlânticos Crioulos. Cabo Verde e S. Tomé e Príncipe numa perspectiva comparada, 2017. (no prelo).

HAGEMEIJER, T.; ZAMORA, A. Fa d'Ambô: past and present. International Journal of the Sociology of Language, v. 239, p. 193-209, 2016.

HENRIQUES, I. C. São Tomé e Príncipe. A invenção de uma sociedade. Lisboa: Veja, 2000.

HLIBOWICKA-WEGLARZ, B. A origem dos crioulos de base lexical portuguesa no Golfo da Guiné. Romanica Cracoviensia, v. 11, p. 177-185, 2012.

HOLM, J. Pidgins and creoles. Cambridge: Cambridge University Press, 1988.

LADHAMS, J. Article agglutination and the african contribution to the Portuguese-based creoles. Black through White, Battlebridge, London, UK, 2007. Disponível em: <https:// www.google.it/url?sa=t\&rct=j\&q=\&esrc=s\&source=web\&cd=1\&cad=rja\&uact=8\&ve $\mathrm{d}=0$ ahUKEwi6zKmvtPHPAhWDxxQKHaPoA1YQFgggMAA\&url=http\%3A\%2F>. Acesso em: 20 jun. 2017.

LOPES, N. da S.; BAXTER, A. Os tongas: contribuição para o estudo do Português Brasileiro. In: SILEL, 2011, Uberlândia. Anais... Uberlândia: EDUFU, v. 2, n. 2, 2011a. MARGARIDO, A. A Lusofonia e os lusófonos: novos mitos portugueses. Lisboa: Edições Universitárias Lusófonas, 2000. 
MATA, I. Polifonias insulares: cultura e literatura de S. Tomé e Príncipe. Lisboa: Edições Colibri, 2010.

MAURER, P. L'angolar. Un créole afro-portugais parlé à São Tomé. Hamburg: Helmut Buske Verlag, 1995.

MAURER, P. A first step towards the analysis of tone in Santomense. In: MICHAELIS, S. (Ed.). Roots of creole structures. Amsterdan: John Benjamins, 2008. p. 253-261.

MAURER, P. Principense. Grammar, texts, and vocabulary of the Afro-Portuguese creole of the island of Principe, Gulf of Guinea. London: Battlebridge Publications, 2009.

NASCIMENTO, Fabiane de Mello Vianna da Rocha Teixeira Rodrigues. O sistema vocálico do Português de São Tomé e o comportamento das vogais médias em contexto pretônico. 2018. 194f. Tese (Doutorado em Letras Vernáculas). Universidade Federal do Rio de Janeiro, Faculdade de Letras, Rio de Janeiro, 2018.

NEGREIROS, A. L. de A. História etnographica da ilha de S. Tomé. Lisboa: Antiga Casa Bertrand, 1895.

POST, M. La situación lingüística del fa d'ambô, foro hispánico (sociolinguística: lenguas en contacto). Amsterdam: Rodopi, 1998.

ROSA, M. F. O ponto e o rumo do ensino ultramarino. Angola: Lello, 1973.

SANTOS, C. M. A formação das estruturas fundiárias e a territorialização das tensões sociais: São Tomé, primeira metade do século XVI. Studia, Porto: Universidade do Porto, v. 54/55, p. 51-91, 1996.

SCHUCHARDT, H. Ueber das Negerportugiesische von Annobom. Sitzungsberichte Wien, v. 116, 1888. p. 193-226.

SEIBERT, G. Os angolares da ilha de São Tomé: náufragos, autóctones ou quilombolas? Dossiê História Atlântica, v. 12, n. 1/2, p. 43-64, 2004.

SEIBERT, G. Comrades, clients and cousins. Colonialism, socialism and democratization in São Tomé and Príncipe. Leiden: Brill, 2006.

SEIBERT, G. São Tomé and Príncipe. In: SPEAR, T. (Ed.). Oxford bibliographies in african studies. New York: Oxford University Press, 2014.

SEIBERT, G. Substrate influence in creoles and the role of transfer in second language acquisition. Studies in Second Language Acquisition, Cambridge, v. 25, n. 2, p. 185-209, 2003.

SILVEIRA, A. C. Ditongos no Português de São Tomé e Príncipe. 2013. 108f. Dissertação (Mestrado em Filologia e Língua Portuguesa) - Faculdade de Letras, Universidade de São Paulo, São Paulo, 2013.

ZAMORA, A. Breve aproximación a la sociolinguística del Fa d'Ambô en Guinea Ecuatorial. Oráfrica, Revista de Oralidad Africana, Espanha, v. 5, p. 71-112, 2009.

ZAMORA, A. Gramática descriptiva del fa d'ambô. Barcelona: CEIBA, 2010. 
